\title{
The Effect of Problem Based Learning Model on Students Mathematic Representation Ability and Student Adversity Quotient at SD Islam Setia Nurul Azmi Medan
}

\author{
Siti Fadillah ${ }^{1}$, Kms. Muhammad Amin Fauzi', Anita Yus ${ }^{3}$ \\ ${ }^{1,2,3}$ Universitas Negeri Medan, Indonesia \\ fadillahsiti94@gmail.com
}

\section{Abstract}

This study aims to determine: (1) how much influence the problembased learning model has on students' mathematical representation abilities, (2) how much influence is the problem based learning model on students' adversity quotient, 3) whether there is an interaction between the learning model and KAM on students' representation abilities, (4) whether there is an interaction between the learning model and KAM on students' adversity quotient, and (5) how to analyze students' mathematical representation abilities seen from the indicators. This research is about quasi-experimental research. The population of this study was all fourth grade students of SD Islam Setia Nurul Azmi Medan in the academic year 2020/2021 which consisted of four classes. Samples were selected by random sample of two classes. The instruments used were the representation ability test and the attitude scale adversity quotient. The data obtained was then analyzed using ANACOVA and ANAVA in the SPSS 20 program. The results showed: 1) the magnitude influence of the PBL model on the mathematical representation ability of 0.931 or $93.1 \%$,2) the magnitude influence of the PBL model on the adversity quotient is 0.967 or $96.7 \%, 3)$ there is an interaction between the initial ability and PBL learning to the mathematical representation ability of students with an Fcount of 3.906 so that Ha is accepted and HO is rejected, 4) there is no interaction between the initial ability and learning PBL to the adversity quotient for students with an Fcount of 0.198 so that HO is accepted, 5) the ability of the student's visual representation indicator is high with an average score in the experimental class 76 and the control class 72, the ability of the student's visual representation indicator is high with an average score in the experimental class 72 and the control class 68, The indicator ability of the students' representation of words or written text was moderate with the average score in the experimental class 65 and the control class 61.
Keywords

problem based

learning; representation ability; adversity quotient (MCA); mathematics software

\section{Introduction}

Primary schools have an important role in shaping students characters and knowledge. Mathematics has an important role in various disciplines and developing human thinking, on that basis mathematics needs to be given to students since elementary school to equip students in thinking skills. NCTM in Fauzi, dkk (2019) establishes five standards for basic mathematical abilities that students must have, namely the ability to (problem solving, 
reasoning, comunication, connection, representation. Based on the state objectives of learning mathematics, one of the abilities that students must have is the ability to represent. This is in line with Putri's (2015: 114) opinion which states that the ability of mathematical representation is needed because it has a role in developing students' minds as a manifest of the learning process that students have carried out. Thus, the ability of mathematical representation is needed by students to find and make a way of thinking in communicating mathematical ideas from abstract to concrete, so it's easier to understand, The facts in the field to be precise at SD Islam Setia Nurul Azmi are in accordance with the results of interviews with four fourth grade teachers at the school that mathematics is still a difficult subject for most students, Even the abilities that students have in learning mathematics, especially the ability of students to represent mathematics, can be said to be still low, This is obtained from the results of preliminary observations by providing mathematical problems with statistical material. From the results of the students' answers, it can be seen that students have not been able to solve math problems well, meaning that students in solving math problems is still low, It can be concluded that the ability of mathematical representation at SD Islam Setia Nurul Azmi Medan is still low.

Every student has different difficulties understanding the concept. To understand mathematics problems, it is necessary to have endurance so that students are able to make difficulties as challenges and opportunities. The individual ability to deal with this difficulty is called the adversity quotient. According to (Nurlaeli, et al; 2018) adversity quotient is an affective aspect that is considered necessary in learning mathematics. Based on the results of students answers when making preliminary observations made by researchers, there are still many students who do not solve these questions, this is adversity quotient or students fighting attitude is still low and students are also unable to pour ideas in solving problems into the form of visual representations. representations of words, and representations of mathematical equations.

One of the reasons for the low mathematical representation ability and adversity quotient of students is the learning process. In Setia Nurul Azmi Islamic Elementary School, generally teachers still apply conventional learning systems. One of mathematics learning that provides opportunities to improve mathematical representation skills and adversity quotient is through student-centered learning and is oriented towards everyday problems. One of the lessons is a problem based learning. Problem based learning provides broader opportunities for students to develop mathematical students representation abilities. Problem based learning begins with providing real problems to help the student understanding. Then students discuss finding solutions to the problems given. During the discussion activities took place, students analyze problems and get information and connect their ideas, then can present it in the form of a mathematical representation such as restating it in a visual form, Mathematical expressions or words to understand mathematical concepts and to solve problems. In addition, it also teaches students to work well together and never give up and motivates each other in group discussions. The next activity, presenting the results of the discussion in front of the class and the other groups in charge of responding. The discussion and presentation process is expected to improve students' mathematical representation skills and adversity quotient. 


\section{Review of Literatures}

The ability of mathematical representation is a process of expressing ideas, students thinks on their understanding of a mathematical problem according to the aspects of representation, namely presenting images, tables, diagrams, write mathematical equations or expressions or explain written words or texts. According to Yudhanegara, et al (2014: 77) NCTM also explained that basically the representation process involves translating a problem or idea into a new form. The process of representation includes converting diagrams or physical models into symbols or words, and the process of representation can also be used in translating or analyzing verbal problems to make their meaning clearer. This understanding is in line with that expressed by Sabirin (2014: 33) that the ability to represent is one of the general goals of learning mathematics in schools. This ability is very important for students and is closely related to communication and problem solving skills. With representation, problems that at first seem difficult can be seen more easily, so that the problems presented can be solved more easily.

Adversity quotient is a person who isn't intelligent to withstand all difficulties to find a way out of solving various kinds of problems by changing the way of thinking of these difficulties. Adversity Quotient (AQ) was first developed by Paul G. Stoltz. A consultant who is very well known in leadership topics in the world of work and skills-based education. AQ helps individuals strengthen their abilities and persistence in facing life isn't daily challenges while sticking to the principles regardless of what happens. According to Stoltz (2000: 12) a person's success in living life is mainly determined by the level of AQ. The AQ is formed into three, namely:

a. A new conceptual framework for understanding and enhancing all the facial features of success.

b. A measure to determine a person who doesn't responsd to adversity.

c. A set of tools for improving ones response to adversity.

Problem based learning was first developed as a learning model in 1970 at the Canadian McMaster Medical School Barret (Damayanti, R \& Aldila, E: 2018). According to Lubis, et al (2018: 53) problem based learning is a learning that makes the problem a learning material to find the concept of knowledge that you want to know. Problem-based learning is an approach based on a problem that requires authentic investigation with the intention of students developing their knowledge so that they can solve the problem. In applying for the PBL learning model, the teacher provides full opportunities for students to be active and participate in learning. According to Arends (Nurleli, et al: 2018) a learning model with an authentic problem approach with the intention of students getting higher-order thinking skills, compose his own knowledge, and develop self-confidence and independence. In applying for the PBL learning model, the teacher provides full opportunities for students to be active and participate in learning. Problem-based learning is a learning model designed and developed to improve students' ability to solve problems. Problems that are used as the focus of learning can be solved by students through group work so that they can provide a variety of learning experiences. 


\section{Research Methods}

This research is about quasi-experimental research, This research was conducted at SD Islam Setia Nurul Azmi Medan T.A 2020/2021. The population in this study were all class IV and the samples in this study were class IV-B and IV-C. Class IV-B is the experimental class and class IV-C which is the control class. The experimental class was given to learning with problem based learning while the control class was given conventional learning. The research design I used was a pretest posttest only design.

Table 1. Pretest Postest Only Control Design

\begin{tabular}{|c|c|c|c|}
\hline Class & Pretest & Treatment & Postest \\
\hline Eksperimen & $\mathrm{T}_{1}$ & $\mathrm{X}$ & $\mathrm{T}_{2}$ \\
\hline Control & $\mathrm{T}_{1}$ & - & $\mathrm{T}_{2}$ \\
\hline
\end{tabular}

Information:

X: Treatment (Learning Using Problem Based Learning)

T1: Representation Ability Pretest and Adversity Quotient scale

T2: Representation Ability Postest and Adversity Quotient Scale

The steps taken in this research are as follows: (1) observation and planning with the principal, and class teachers, make rpp, compile a research schedule and arrange research permits; (2) determine the class that will be used as a sample, provide an initial ability test to the experimental class and control class, give a pretest of representation ability, and the adversity quotient in both classes, provide learning in the experimental class given problem based learning and the control class is given conventional learning, then given postest representation ability and adversity quotient; (3) data analysis; (4) preparation of reports; (5) evaluation.

\section{Discussion}

4.1 How Much Influence does the PBL Model have on the Mathematical Representation Ability

Table 2. Interpretation of the Correlation Coefficient of Students' Mathematical Representation Ability Model Summary

\begin{tabular}{|c|c|c|c|c|}
\hline Model & $\mathrm{R}$ & $\mathrm{R}$ Square & $\begin{array}{c}\text { Adjusted R } \\
\text { Square }\end{array}$ & $\begin{array}{c}\text { Std. Error of the } \\
\text { Estimate }\end{array}$ \\
\hline 1 &, $931^{\mathrm{a}}$ &, 867 &, 865 & 5,073 \\
\hline
\end{tabular}

a. Predictors: (Constant), Kelas, Pretes

The table above explains the value of the correlation correlation $(\mathrm{R})$ which is equal to 0.931. From this output, the coefficient of determination ( $\mathrm{R}$ Square) is 0.867 , which means that the relationship between the independent variable and the dependent variable is $86.7 \%$. This shows that the mathematical representation ability of students is influenced by the 
problem based learning model by $86.7 \%$ and only $13.3 \%$ is influenced by other factors in improving students' mathematical representation abilities.

Table 3. Model Summary

ANOVA $^{\mathrm{a}}$

\begin{tabular}{|c|c|c|c|c|c|c|}
\hline \multicolumn{1}{|c|}{ Model } & Sum of Squares & df & Mean Square & F & Sig. \\
\hline \multirow{4}{*}{1} & Regression & 9771,272 & 1 & 9771,272 & 379,616 &, $000^{b}$ \\
& Residual & 1492,911 & 58 & 25,740 & & \\
& Total & 11264,183 & 59 & & & \\
\hline
\end{tabular}

a. Dependent Variable: Postes

b. Predictors: (Constant),Pretes

From this output it is known that the value of Fcount $=378.616$ with a significant level of $0.000<0.05$, then the regression model can be used to predict the KRM variable or in other words the effect of the learning model on KRM.

Table 4.Significance Level and Regression Coefficient

\begin{tabular}{|c|c|c|c|c|c|}
\hline \multirow[t]{2}{*}{ Model } & \multicolumn{2}{|c|}{ Unstandardized Coefficients } & \multirow{2}{*}{$\begin{array}{c}\begin{array}{c}\text { Standardized } \\
\text { Coefficients }\end{array} \\
\text { Beta }\end{array}$} & \multirow[t]{2}{*}{$\mathbf{t}$} & \multirow[t]{2}{*}{ Sig } \\
\hline & B & Std. Error & & & \\
\hline (Constant) & 34,402 & 1,882 & & 18,277 &, 000 \\
\hline Pretes & ,738 & ,038 & ,931 & 19,484 & ,000 \\
\hline
\end{tabular}

a. Dependent Variable: Postes

A simple regression model is declared feasible if the significance value is smaller than the significance level is smaller than the significance level. The table above shows that the significance value is $0.000<0.05$. So that the data is feasible. From the results of the calculation of the learning model variable regression on the mathematical representation ability, it is found that the constant (a) is 34.402 and the regression coefficient (b) of the learning model (class) variable is 0.738 . Thus, from the calculation it can be determined that the regression equation is $\mathrm{Y}=34.402+0.738 \mathrm{X}$. Where, $\mathrm{Y}$ is the ability of mathematical representation and $\mathrm{X}$ is the learning model (class), to see the relationship of the independent variable to the dependent variable, then a correlation analysis is carried out between the independent variables and the dependent variable. The obtained correlation coefficient is 0.931. Based on the regression interpretation table, the coefficient value of 0.931 or $93.1 \%$ means that it is at a strong relationship level.

\subsection{How Much Influence does the PBL Model have on the Adversity Quotient}

Table 5. Interpretation of the Correlation Coefficient of Student Adversity Quotient Data Model Summary

\begin{tabular}{|c|c|c|c|c|}
\hline Model & R & R Square & Adjusted R Square & $\begin{array}{c}\text { Std. Error of the } \\
\text { Estimate }\end{array}$ \\
\hline 1 &, $967^{\mathrm{a}}$ &, 936 &, 935 & 2,498 \\
\hline
\end{tabular}

a. Predictors: (Constant), AQ_Pretes 
The table above explains the magnitude of the correlation value (R), which is 0.967 . From this output, the coefficient of determination ( $\mathrm{R}$ Square) is 0.936 , which implies that the relationship of the independent variable to the dependent variable is $93.6 \%$. This shows that the ability of students' adversity quotient is influenced by the problem based learning model by $93.6 \%$ and only $6.4 \%$ was influenced by other factors in the students' adversity quotient ability.

Table 6. Model Summary ANOVA $^{\mathrm{a}}$

\begin{tabular}{|c|c|c|c|c|c|c|}
\hline \multicolumn{1}{|c|}{ Model } & Sum of Squares & df & Mean Square & F & Sig. \\
\hline \multirow{2}{*}{1} & Regression & 5287,681 & 1 & 5287,681 & 847,426 &, $000^{\mathrm{b}}$ \\
& Residual & 361,903 & 58 & 6,240 & & \\
& Total & 5649,583 & 59 & & & \\
\hline
\end{tabular}

a. Dependent Variable: AQ_Postes

b. Predictors: (Constant), AQ_Pretes

From this output it is known that the value of $\mathrm{F}$ count $=847,426$ with a significance level of $0.000<0.05$, then the regression model can be used to predict the Adversity Quotient variable or in other words, the influence of the learning model on the Adversity Quotient.

Table 7. Significance Level and Regression Coefficient Coefficients $^{\mathrm{a}}$

\begin{tabular}{|cc|c|c|c|c|c|}
\hline \multirow{2}{*}{\multicolumn{2}{|c|}{ Model }} & \multicolumn{2}{|c|}{$\begin{array}{c}\text { Unstandardized } \\
\text { Coefficients }\end{array}$} & $\begin{array}{c}\text { Standardized } \\
\text { Coefficients }\end{array}$ & \multirow{2}{*}{ Sig. } & \\
\cline { 3 - 5 } & & B & Std. Error & Beta & & \\
\hline \multirow{2}{*}{1} & (Constant) &, 323 & 2,461 & &, 131 &, 896 \\
& AQ_Pretes & 1,115 &, 038 &, 967 & 29,111 &, 000 \\
\hline
\end{tabular}

a. Dependent Variable: AQ_Postes

A simple linear regression model is declared feasible if the significance value is smaller than the significance level. The table above shows that the significance value is $0.000<0.05$. So that the data is feasible. From the results of the calculation of the learning model variable regression to the Adversity Quotient, the constant (a) is 0.323 and the regression coefficient (b) of the learning model (class) variable is 1.115. Therefore, From the calculation it can be determined that the regression equation is $\mathrm{Y}=0.323+1.115 \mathrm{X}$. Where $\mathrm{Y}$ is Adversity Quotient and $\mathrm{X}$ learning model (class), to see the relationship of the independent variable to the dependent variable, then a correlation analysis is carried out between the independent variables and the dependent variable. The obtained correlation coefficient is 0.967. Based on the regression interpretation table, the coefficient value is 0.967 or $96.7 \%$ means the level of a strong relationship.

\subsection{Is there any Interaction between PBL and KAM Learning on Mathematical Representation Skills}


Based on question number three on the formulation of the problem, the statistical hypothesis test used is Anava. The results of calculations using SPSS are shown as follows:

Table 8. Results of Interaction Test between Learning PBL and KAM on Mathematical Representation Ability

\begin{tabular}{|c|c|c|c|c|c|}
\hline Source & $\begin{array}{c}\text { Type III Sum of } \\
\text { Squares }\end{array}$ & df & Mean Square & F & Sig. \\
& $4162,800^{\mathrm{a}}$ & 2 & 2081,400 & 16,707 &, 000 \\
Corrected Model & 28116,222 & 1 & 28116,222 & 225,678 &, 000 \\
Intercept & 3910,650 & 1 & 3910,650 & 31,389 &, 000 \\
KAM & 486,660 & 1 & 486,660 & 3,906 &, 003 \\
Kelas & 7101,383 & 57 & 124,586 & & \\
Error & 295133,000 & 60 & & & \\
Total & 11264,183 & 59 & & & \\
Corrected Total & & & & \\
\hline
\end{tabular}

The table above shows that the significance value of the interaction is 0.003 . . This value is smaller than the predetermined significance level of 0.05 . So that the testing of hypothesis 3 is if the significance value is smaller than the significance level of the provisions then $\mathrm{Ha}$ is accepted and in the results of the calculation, it is found that the calculated value is 0.003 <from 0.05 with an Fcount value of 3.906, so that Ha is accepted and H0 is rejected, it means that there is an interaction between the initial ability and PBL learning towards the mathematical representation ability of students. In other words, the increase in students 'mathematical representation abilities is caused by differences in the learning used and because of the students' initial mathematical abilities.

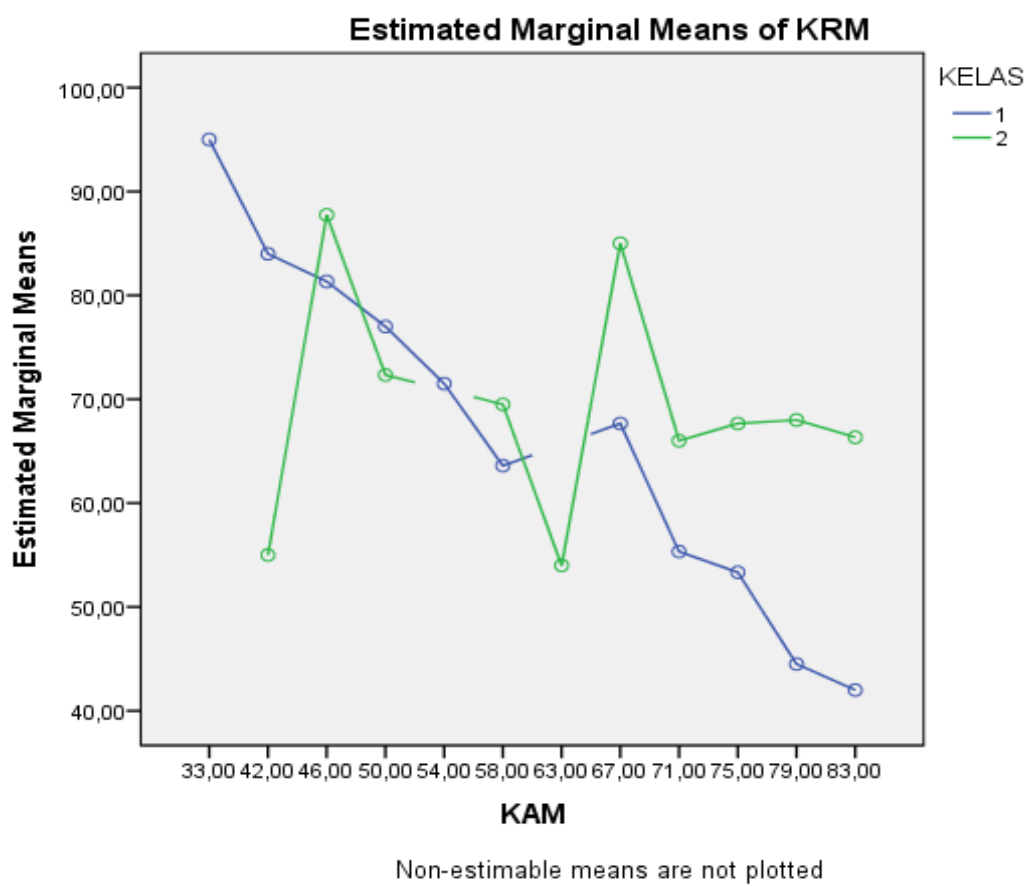

Figure 1. Interaction Graph 


\subsection{Is there any Interaction between PBL and KAM Learning on Adversity Quotient}

Table 9. Results of Interaction Test between PBL Learning and KAM on Adversity Quotient

Tests of Between-Subjects Effects

Dependent Variable: Adversity Quations

\begin{tabular}{|c|c|c|c|c|c|}
\hline Source & $\begin{array}{c}\text { Type III Sum } \\
\text { of Squares }\end{array}$ & df & Mean Square & F & Sig. \\
\hline Corrected & $20,950^{\mathrm{a}}$ & 2 & 10,475 &, 106 &, 900 \\
Model & 12019,354 & 1 & 12019,354 & 121,717 &, 000 \\
Intercept &, 533 & 1 &, 533 &, 005 &, 942 \\
KAM & 19,560 & 1 & 19,560 &, 198 &, 658 \\
Kelas & 5628,634 & 57 & 98,748 & & \\
Error & 310956,250 & 60 & & & \\
Total & 5649,583 & 59 & & & \\
Corrected Total & 56250 \\
\hline
\end{tabular}

a. $\mathrm{R}$ Squared $=, 004$ (Adjusted R Squared $=-, 031$ )

The table above shows that the significance value for the interaction is 0.658 . This value is greater than the predetermined significance level of 0.05 . So that the testing of hypothesis 4 is if the significance value is smaller than the significance level of the provisions then $\mathrm{Ha}$ is accepted and in the results of the calculation, it is found that the value of the count is $0.658>$ from 0.05 with an Fcount of 0.198 so that $\mathrm{H} 0$ is accepted, meaning that there is no interaction between the initial ability and PBL learning on the adversity quotient of students. In other words, the increase in the adversity quotient of students was caused by differences in the learning used, not because of the students' initial abilities. 


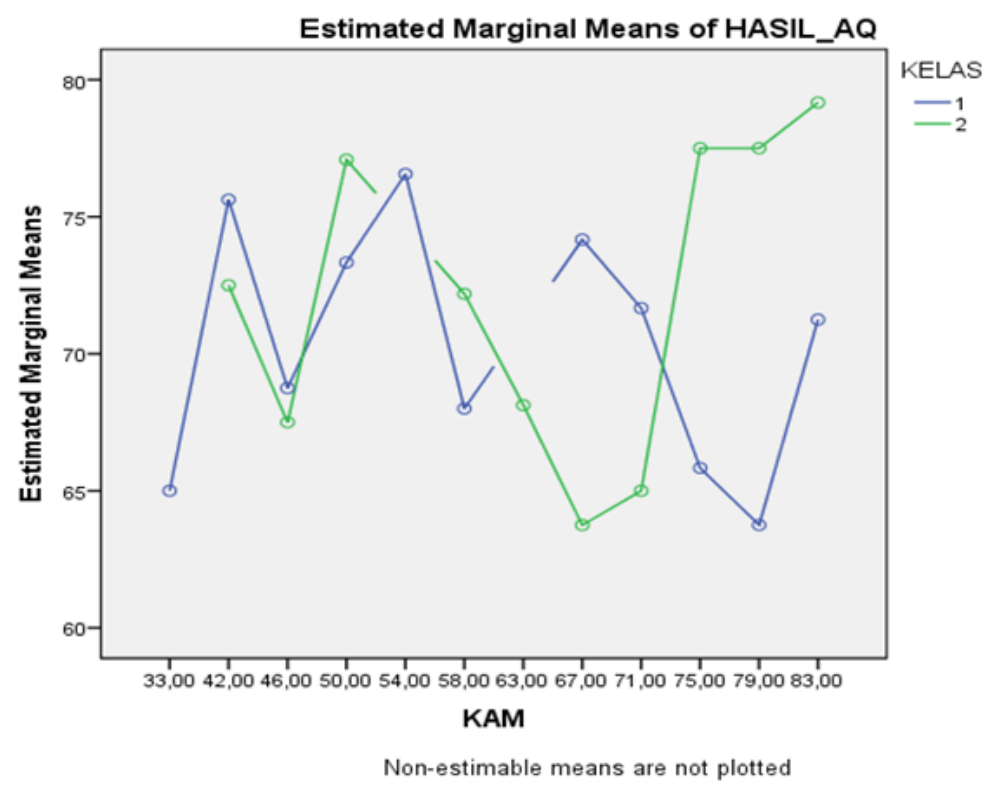

Figure 2. Interaction Graph

4.5 How is the Analysis of Students' Mathematical Representation Abilities Seen From the Indicators

a. Indicators Visual Representation

Table 10. Visual Representation Level Indicator

\begin{tabular}{|c|c|c|c|c|c|}
\hline \multicolumn{3}{|c|}{ Experiment Class } & \multicolumn{2}{c|}{ Control Class } & \\
\hline Value Interval & $\begin{array}{c}\text { Total of } \\
\text { Students }\end{array}$ & $\begin{array}{c}\text { Average } \\
\text { Percentage }\end{array}$ & $\begin{array}{c}\text { Total of } \\
\text { Students }\end{array}$ & $\begin{array}{c}\text { Average } \\
\text { Percentage }\end{array}$ & $\begin{array}{c}\text { Assessment } \\
\text { Criteria }\end{array}$ \\
\hline $0 \leq \mathrm{KBKM} \leq 50$ & 1 & $3 \%$ & 5 & $17 \%$ & Low \\
\hline $50 \leq \mathrm{KBKM} \leq 80$ & 20 & $67 \%$ & 17 & $57 \%$ & Medium \\
\hline $80 \leq \mathrm{KBKM} \leq 100$ & 9 & $30 \%$ & 8 & $27 \%$ & High \\
\hline Lowest Value & \multicolumn{2}{|c|}{50} & & 50 & \\
\hline Highest Value & \multicolumn{2}{|c|}{700} & & 300 \\
\hline Average & \multicolumn{2}{|c|}{14,306} & & 34,759 \\
\hline Deviation Standar & \multicolumn{2}{|c|}{} \\
\hline
\end{tabular}

From the table above, it can be seen that the average visual representation indicator in the control class is 72 and the experimental class is 76 .

b. Indicator Representation of Mathematical Equations or Expressions

Tabel 11. Indicator Levels of Representation of Mathematical Equations or Expressions

\begin{tabular}{|l|l|l|l|l|l|}
\hline \multicolumn{3}{|c|}{ Experiment Class } & \multicolumn{2}{c|}{ Control Class } & \\
\hline Value Interval & Total of & Average & Total of & Average & Assessment \\
\hline
\end{tabular}




\begin{tabular}{|c|c|c|c|c|c|}
\hline & Students & Percentage & Students & Percentage & Criteria \\
\hline $0 \leq \mathrm{KBKM} \leq 50$ & 6 & $20 \%$ & 6 & $20 \%$ & Low \\
\hline $50 \leq \mathrm{KBKM} \leq 80$ & 20 & $67 \%$ & 23 & $77 \%$ & Medium \\
\hline $80 \leq \mathrm{KBKM} \leq 100$ & 4 & $13 \%$ & 1 & $3 \%$ & High \\
\hline Lowest Value & \multicolumn{2}{|c|}{100} & \multicolumn{3}{|c|}{100} \\
\hline Highest Value & \multicolumn{2}{|c|}{72} & \multicolumn{3}{|c|}{12,962} \\
\hline Average & \multicolumn{2}{|c|}{14,735} & & \\
\hline Deviation Standar & \multicolumn{2}{|c|}{}
\end{tabular}

From the table above, it can be seen that the average indicator representation of mathematical equations or expressions in the control class is 68 and the experimental class is 72 .

\section{c. Indicator of Representation of Words or Written Text}

Table 12. Level Indicator Representation of Words or Written Text

\begin{tabular}{|c|c|c|c|c|c|}
\hline \multicolumn{3}{|c|}{ Experiment Class } & \multicolumn{2}{|c|}{ Control Class } & \multirow[b]{2}{*}{$\begin{array}{l}\text { Average } \\
\text { Percentage }\end{array}$} \\
\hline Value Interval & $\begin{array}{l}\text { Total of } \\
\text { Students }\end{array}$ & $\begin{array}{l}\text { Average } \\
\text { Percentage }\end{array}$ & $\begin{array}{l}\text { Value } \\
\text { Interval }\end{array}$ & $\begin{array}{l}\text { Total of } \\
\text { Students }\end{array}$ & \\
\hline $0 \leq \mathrm{KBKM} \leq 50$ & 4 & $13 \%$ & 8 & $27 \%$ & Low \\
\hline $50 \leq \mathrm{KBKM} \leq 80$ & 23 & $77 \%$ & 21 & $70 \%$ & Medium \\
\hline $80 \leq \mathrm{KBKM} \leq 100$ & 3 & $10 \%$ & 1 & $3 \%$ & High \\
\hline Lowest Value & \multicolumn{2}{|r|}{38} & \multicolumn{3}{|c|}{33} \\
\hline Highest Value & \multicolumn{2}{|c|}{100} & \multicolumn{3}{|c|}{88} \\
\hline Average & \multicolumn{2}{|c|}{65} & \multicolumn{3}{|c|}{61} \\
\hline Deviation Standar & \multicolumn{2}{|c|}{14,781} & \multicolumn{3}{|c|}{14,618} \\
\hline
\end{tabular}

From the table above, it can be seen that the average indicator for the representation of words or written text in the control class is 61 and the experimental class is 65 .

\section{Conclusion}

1. The magnitude influence of the problem-based learning model on the representation ability based on the regression interpretation table, the coefficient value of 0.867 or $86.7 \%$ means that it is at the level of a strong relationship.

2. The magnitude effect of the problem-based learning model on adversity quotient based on the regression interpretation table, the coefficient value of 0.967 or $96.7 \%$ means that it is at a moderate level of relationship.

3. There is an interaction between learning and KAM on students' mathematical representation abilities with a value of 0.003 < from 0.05 with an Fcount of 3.906.

4. There is no interaction between learning and KAM on students' adversity quotient that the count value is $0.658>$ from 0.05 with an Fcount value of 0.198 .

5. Analysis of students' mathematical representation abilities seen from each indicator has increased. The average visual representation indicator in the control class is 72 and the 
experimental class is 76 , the average indicator representation of mathematical equations or expressions in the control class is 68 and the experimental class is 72 , while the average indicator of representations of words or written text in the control class amounted to 61 and the experimental class was 65 .

\section{References}

Adliani, S., Asmin, Hasratuddin. 2020. The Influence of Realistic Mathematical Approach to Understanding Concept and the Mathematical Connection Ability of Islamic Private Vocational School Students Hikmatul Fadhillah Medan Class VII. Budapest International Research and Critics in Linguistics and Education (BirLE) Journal (3): 487-499.

Damayanti, R. \& Aldila, E., A. 2018. Perbandingan Kemampuan Representasi Matematis Siswa antara CTL \& PBL. JIPM. Vol 7 (1) : 30-39.

Fauzi, Kms Muhammad Amin, Maryunah, Edi Syahputra (2019). Peningkatan Kemampuan Komunikasi Matematis dan Kemandirian Belajar Siswa dengan Menggunakan Model Pembelajaran Reciprocal Teaching. Jurnal Tematik. Jilid (9) 234-245 [Online]. Diakses di https //scholar.google.co.id/citations?user=GZGhcIAAAAAJ\&hl=id. pada tanggal 21 Januari 2020

Imelda, Anzelina, D. 2019. Students' Activities in Learning with Problem Based Learning Based Module to Enhance Students' HOTS on the Subject of Straight Line Equations Budapest International Research and Critics in Linguistics and Education (BirLE) Journal (2): 552-559.

Lubis, Chairi Mutia and Rajagukguk, Waminton and Fauzi, Kms Muhammad Amin (2018) Differences in Metacognitive Ability of Students Through Learning Realistic Mathematics Education and Problem Based Learning in Pangkalan Susu Senior High School. In: Proceedings of The 3rd Annual International Seminar on Transformative Education and Educational Leadership (AISTEEL), 03-04 October 2018, Emerald Garden Hotel, Medan City, North Sumatera, Indonesia.

Nurlaeli., Noornia. A., \& Dwi, E.W. (2018). Pengaruh Model Pembelajaran Problem Based Learning Terhadap Kemampuan Berpikir Kritis Matematis Siswa Ditinjau dari Adversity Quotient. Fibonacci. Vol 4 (2): 145-152.

Nurlaeli., Noornia. A., \& Dwi, E.W. (2018). Pengaruh Model Pembelajaran Problem Based Learning Terhadap Kemampuan Berpikir Kritis Matematis Siswa Ditinjau dari Adversity Quotient. Fibonacci. Vol 4 (2): 145-152.

Putri, H. E. 2015. The Influence of Concrete Pictorial Abstract (CPA) Approach to the Mathematical Representation Ability Achievement of the Pre Service Teachers at Elementary School. International Journal of Education and Research. Vol 3 No. 1

Pohan, A. M., Asmin, Menanti, A. 2020. The Effect of Problem Based Learning and Learning Motivation of Mathematical Problem Solving Skills of Class 5 Students at SDN 0407 Mondang. Budapest International Research and Critics in Linguistics and Education (BirLE) Journal (3): 531-539.

Rezeki, R., Sitompul, H., and Situmorang, J. 2020. The Effect of Learning Strategies and Cognitive Styles on Learning Outcomes of Mathematics after Controlling Intelligence. Budapest International Research and Critics in Linguistics and Education (BirLE) Journal (3): 1151-1163.

Sabirin, M. 2014. Representasi dalam Pembelajaran Matematika. JPM IAIN. Antasari Banjarmasin. Vol 1(2): 33-34. 
Stoltz, G. P. 2000. Adversity Quotient Mengubah Hambatan Menjadi Peluang. Jakarta: PT. Grasindo.

Sugiyono. 2017. Metode Penelitian Pendidikan. Bandung: Alfabeta.

Tarigan, E. E., Hasratuddin, Fauzi, K. M. A. 2020. Development of Students Work Sheet Based on Realistic Mathematic Approach with Ethnomatematic nuanced to Improve Critical Thinking of 4th Grade Students in Primary School (SD Negeri 091358 Haranggaol, Haranggaol Horisan Sub-District). Budapest International Research and Critics in Linguistics and Education (BirLE) Journal (3): 133-143.

Yudhanegara, dkk. 2014. Meningkatkan Kemampuan Representasi Beragam Matematis Siswa Melalui Pembelajaran Berbasis Masalah Terbuka. Jurnal Ilmiah Solusi. Universitas Singaperbangsa Karawang: FKIP Program Studi Pendidikan Matematika. Vol 1 (3) 76-85. 